\title{
MENDIDIK PENERUS BANGSA, BESINERGIS BERSAMA, DAN BERORGANISIR POTENSI UNTUK INDONESIA YANG LEBIH SEJAHTERA DI KAMPUNG CIGARUNG DESA KALONG 1
}

\author{
Yono $^{1}$, Tita Alfatiaga Irdianiza, Rinienta Andiani ${ }^{2}$ \\ alfatiaga@gmail.com \\ Dosen Fakultas Agama Islam¹, Mahasiswa KKN Kelompok 63 Tahun $2018^{2}$
}

\begin{abstract}
ABSTRAK
Universitas Ibn Khaldun Bogor merupakan salah satu Universitas yang mengadakan Kuliah Kerja Nyata, bagian integral dalam proses pendidikan yang merupakan usaha sadar untuk menyiapkan mahasiswa melalui kegiatan bimbingan, pengajaran dan atau latihan agar mau dan dapat melaksanakan perannya dimasa yang akan datang, sesuai dengan yang diharapkan. Kuliah Kerja Nyata merupakan proses pembelajaran mahasiswa melaui sebagai kegiatan langsung ditengah-tengah masyarakat, dan mahasiswa berupaya untuk menjadi bagian dar masyarakat secara aktif dan kreatif terlibat daam dinamika yang terjadi di masyarakat. Mahasiswa mempunyai peran strategis sebagai agen perubahan. Kuliah Kerja Nyata (KKN) adalah salah satu wujud pengabdian mahasiswa kepada masyarakat lewat pemberian bantuan, pemberdayaan, pelatihan, penyuluhan, pendampingan dan untuk menyadarkan potensi yang dimiliki, serta membantu meningkatkan kualitas hidup dan pembangunan. mahasiswa akan mendapatkan kemampuan generatif berupa life keterampilan hidup. Metode pendekatan yang digunakan dalam kegiatan ini adalah : (1) pendekatan berdasarkan karakter masyarakat, (2) pendekatan organisai, (3) pendekatan religius, (4) pendekatan kekerabatan, (5) pendekatan edukasi. Hasil yang dicapai adalah masyarakat memiliki kesadaran akan pentingnya lingkungan yang aman dan nyaman untuk mendukung pola hidup sehat dan masyarakat mempunyai sarana prasarana dalam menjaga lingkungan sekitarnya.
\end{abstract}

Kata Kunci : KKN, Pemberdayaan, Program Kerja

\section{PENDAHULUAN}

\section{Latar Belakang}

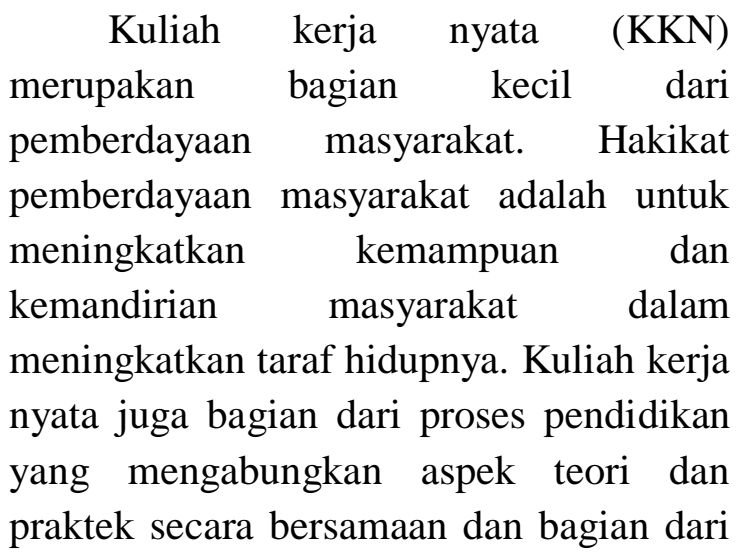

Tri Dharma Perguruan Tinggi. Kegiatan ini merupakan salah satu tujuan pencapaian yang harus dilakukan oleh perguruan tinggi. Tujuan lain dari KKN ini adalah menempatkan mahasiswa di luar kampus agar mahasiswa hidup ditengahtengah masyarakat bersama masyarakat memanfaatkan potensi sumber daya alam lokal dan sumber daya manusia yang ada untuk mengatasi permasalahan masyarakat dalam kurun waktu tertentu. Kuliah kerja 
nyata dituntut untuk melahirkan orangorang yang memiliki semangat tinggi dan memiliki pemikiran yang kritis, kreatif, mandiri, Inovatif dan tujuan lainnya yaitu untuk mencapai akselerasi dan efektifitas dalam program pembangunan masyarakat.

Pendidikan dalam arti luas berarti suatu proses untuk mengembangkan semua aspek kepribadian manusia, yang mencakup pengetauannya, nilai serta sikapnya dan ketrampilannya. ( Achmad Munib, 2004 )

Pendidikan nonformal dengan berbagai atribut dan nama atau istilah lainnya, baik disebut dengan, mass education, adult education, lifelong education, learning society,out-of-school education, social education dll, merupakan kegiatan yang terorganisir dan sistematis yang diselenggarakan di luar subsistem pendidikan formal. ( Sudjana, 1994.). Meskipun kesemua istilah tersebut memiliki perbedaan dan kesamaan dengan pendidikan nonformal, akan tetapi sangat sulit untuk merumuskan pengertian yang konprehensif dan berlaku umum, mengingat titik pandang yang berbeda.

Sasaran pendidikan nonformal dapat ditinjau dari beberapa segi, yakni pelayanan, sasaran khusus, pranata sistem pengajaran dan pelembagaan program. Ditilik dari segi pelayanan, sasaran pendidikan nonformal adalah melayani anak usia sekolah (0-6 tahun), anak usia sekolah dasar (7-12 tahun), anak usia pendidikan menengah (13-18 tahun), anak usia perguruan tinggi (19-24 tahun). Ditinjau dari segi sasaran khusus, pendidikan nonformal mendidik anak terlantar, anak yatim piatu, korban narkoba, perempuan penghibur, anak berkebutuhan khusus. Dari segi pranata, penyelenggaraan kegiatan pembelajaran dilakukan dilingkungan keluarga, pendidikan perluasan wawasan desa dan pendidikan keterampilan. Di segi layanan masyarakat, sasaran pendidikan nonformal antara lain membantu masyarakat melalui program PKK, , TPQ, TPA, TK, KB, perawatan bayi, peningkatan gizi keluarga, pengetahuan rumah tangga dan penjagaan lingkungan sehat. Dilihat dari segi pengajaran, sasaran pendidikan nonformal sebagai penyelenggara dan pelaksana program kelompok, organisasi dan lembaga pendidikan, program kesenian tradisional ataupun kesenian modern lainnya yaitu menjadi fasilitator bahkan turut serta dalam program keagamaan, seperti mengisi pengajaran di majelis taklim, di pondok pesantren, dan bahkan di beberapa tempat kursus. Sedangkan sasaran pendidikan nonformal ditinjau dari segi pelembagaan, yakni kemitraan atau bermitra dengan berbagai pihak penyelenggara program pemberdayaan masyarakat berkoordinasi dengan desa atau pelaksana program pembangunan.

Universitas Ibn Khaldun Bogor merupakan salah satu Universitas yang mengadakan Kuliah Kerja Nyata, bagian integral dalam proses pendidikan yang merupakan usaha sadar untuk menyiapkan mahasiswa melalui kegiatan bimbingan, pengajaran dan atau latihan agar mau dan dapat melaksanakan perannya dimasa yang akan datang, sesuai dengan yang diharapkan. Dengan demikian KKN merupakan proses pendidikan untuk mengamalkan ilmu pengetahuan, teknologi dan seni secara melembaga langsung kepada masyarakat dengan tujuan utama membentuk sarjana-sarjana siap dan berguna serta membantu proses pembangunan sosial.

Pembekalan KKN diselenggarakan oleh Bupati Bogor Dan pihak LPPM pada tanggal 7 Agustus 2018 di Masjid Raya Al 
- Hijr 2 dan membekali mahasiswa dengan materi pemberdayaan masyarakat melalui $\mathrm{KKN}$, materi tentang POSDAYA, serta materi yang terkait dengan teknis kegiatan KKN. Melakukan koordinasi dengan Dosen Pembimbing Lapangan (DPL) KKN kelompok secara efektif. Mahasiswa KKN juga mengadakan pertemuan secara rutin membahas program kerja dan selalu melakukan evaluasi setiap selesai melakukan program kerja. Ketika penerjunan ke lokasi KKN, para mahasiswa melakukan kegiatan observasi dan silahturami guna untuk melihat kondisi yang ada di sekitar lokasi KKN. Kegiatan ini dilakukan sebelum mahasiswa benar-benar terjun ke lokasi KKN. Kegiatan ini dilakukan untuk mengamati secara langsung terhadap situasi, kondisi, sarana, dan pasarana yang ada di lokasi KKN dalam hal ini Desa guna mendukung proses kuliah kerja nyata di Desa Kalong I lebih tepatnya di $\begin{array}{llllll}\text { Kampung } & \text { Cigarung } & \text { RT } & 11 & \text { RW } & 04\end{array}$ tersebut.

\section{Analisis Situasi}

Berdasarkan observasi dan analisis yang telah kelompok kami lakukan di Desa Kalong I Kecamatan Leuwisadeng memiliki wilayah administrative Desa Kalong I terdiri dari 04 RW dengan 15 RT.

Secara keseluruhan Desa Kalong I memiliki luas wilayah 344,6 Ha. Desa Kalong I memiliki kelembapan dengan suhu 25-30 ${ }^{\circ} \mathrm{C}$. Jumlah penduduk keseluruhan Desa Kalong I adalah 5.626 jiwa dengan penjabaran, jumlah laki-laki 2.350 dan jumlah perempuan 2.213. Secara umum dapat dijelaskan bahwa penduduk Desa Kalong I bermata pencaharian Wiraswasta, pedagang, dan selebihnya mempunyai mata pencaharian yang bervariasi contohnya membuat golok, bercocok tanam, dan berkebun.

Dan dalam hal ini terdapat banyak sekolah yang terdiri dari paud, SD, dan SMP.

Masyarakatpun sangat antusias dalam hal pendidikan, hal itu dibuktikan dengan cukup banyaknya siswa yang bertempat tinggal cukup jauh dari sekolah, dengan jarak sekitar 3-5 Km.

Pada podemik didalam masyarakat terdapat kegiatan masyrakat yaitu pengajian ibu-ibu yang terjadwalkan setiap seminggu sekali dihari senin pagi dan terdapat pengajian anak-anak juga .

\section{Kondisi Geografis}

Desa Kalong I adalah salah satu desa di wilayah Kecamatan Leuwisadeng, Kabupaten Bogor. Kecamatan Leuwisadeng mempunyai luas wilayah 3.532,54 hektar. Untuk lebih jelas mengetahuin keadaan geografis Desa Kalong I dapat dilihat pada tabel berikut :

\begin{tabular}{|l|l|}
\hline LUAS WILAYAH & $\mathbf{3 4 4 , 6}$ Ha \\
\hline JUMLAH JIWA & $\mathbf{5 . 6 2 6}$ jiwa \\
\hline Batas wilayah: & \\
\hline a. Sebelah Utara & $\begin{array}{l}\text { Desa } \\
\text { Banyuresmi }\end{array}$ \\
\hline b. Sebelah elatan & Desa Batu Tulis \\
\hline c. Sebelah Barat & Desa Cigudeg \\
\hline d. Sebelah Timur & Desa Kalong II \\
\hline
\end{tabular}




\section{Kondisi Masyarakat}

1. Aspek Pendidikan

Dilihat dari segi pendidikan, Desa Kalong I memiliki anak-anak yang sangat antusias terhadap sesuatu hal. Tetapi masih tetap memiliki permasalahan yang penting dalam bidang pendidikan yang harus diselesaikan. Permasalahan itu berada di orang tua setiap anak karena kurangnya perhatian dari orangtua akan pendidikan anakanaknya. Orangtua yang jarang membantu anak-anak menjadi malas belajar ketika sudah pulang dari sekolah. Anak usia dini berkembang sesuai dengan lingkungannya, perilaku anak usia dapat dibentuk sesuai dengan sikap yang diajarkan oleh orangtuanya masing-masing. Sehingga faktor utama yang terpenting adalah pendidikan di dalam keluarga itu sendiri.

2. Aspek Kegamaan

Dalam aspek keagamaan di Desa Kalong I sudah baik, karena telah di adakannya pengajian rutin ibu-ibu dan bapak-bapak setiap minggunya. Namun, untuk anakanak masih minim TPQ terutama di kampung Cigarung.

3. Aspek Kesehatan

Kampung

Cigarung mempunyai sarana kesehatan yang baik untuk warganya. Dan sarana yang telah di sediakan sangat di manfaatkan sekali oleh warga Kampung Cigarung.

4. Aspek Ekonomi

Perekonomian masyarakat di Kampung Cigarung tidak tergolong kedalam masyarakat yang kekurangan dalam hal finansial. Karena di lihat dari survey di lapangan yang di jalani selama 1 bulan, setiap warga mempunyai pekerjaan dengan penghasilan tetap setiap bulannya, sehingga dapat memenuhi kebutuhan hidup keluarganya setiap bulannya.

5. Aspek Lingkungan.

Di lihat dari aspek lingkungan, kurangnya kesediaan air bersih di Kampung Cigarung. Permasalahan ini dampak dari musim kemarau.

\section{Permasalahan Yang Dihadapi}

Ada beberapa permasalahan yang terdapat di Kampung Cigarung Desa Kalong I Kecamatan Leuwisadeng Kab. Bogor, diantaranya:

1. Tidak adanya TPQ di Kampung Cigarung Desa Kalong I.

2. Kurangnya minat anak dalam menabung.

3. Kurangnya perhatian orangtua dalam mengawasi anak.

4. Kurangnya air bersih.

5. Renggangnya satu blok rumah dengan blok lainnya meski satu RT

6. Kurangnya pemahaman masyarakat mengenai tatacara jual beli tanah yang sesuai prosedur Negara.

7. Kurangnya pemahaman masyarakat mengenai pembuatan surat-surat penting (akte kelahiran,surat nikah Dll).

8. Kurangnya pemahaman masyarakat mengenai pemberian Vitami A terhadap balita. 


\section{METODOLOGI PENGABDIAN}

\section{Tahap Pelaksanaan}

Tahap pelaksanaan untuk kegiatan ini sebagaimana terlihat pada bagan sebagai berikut :

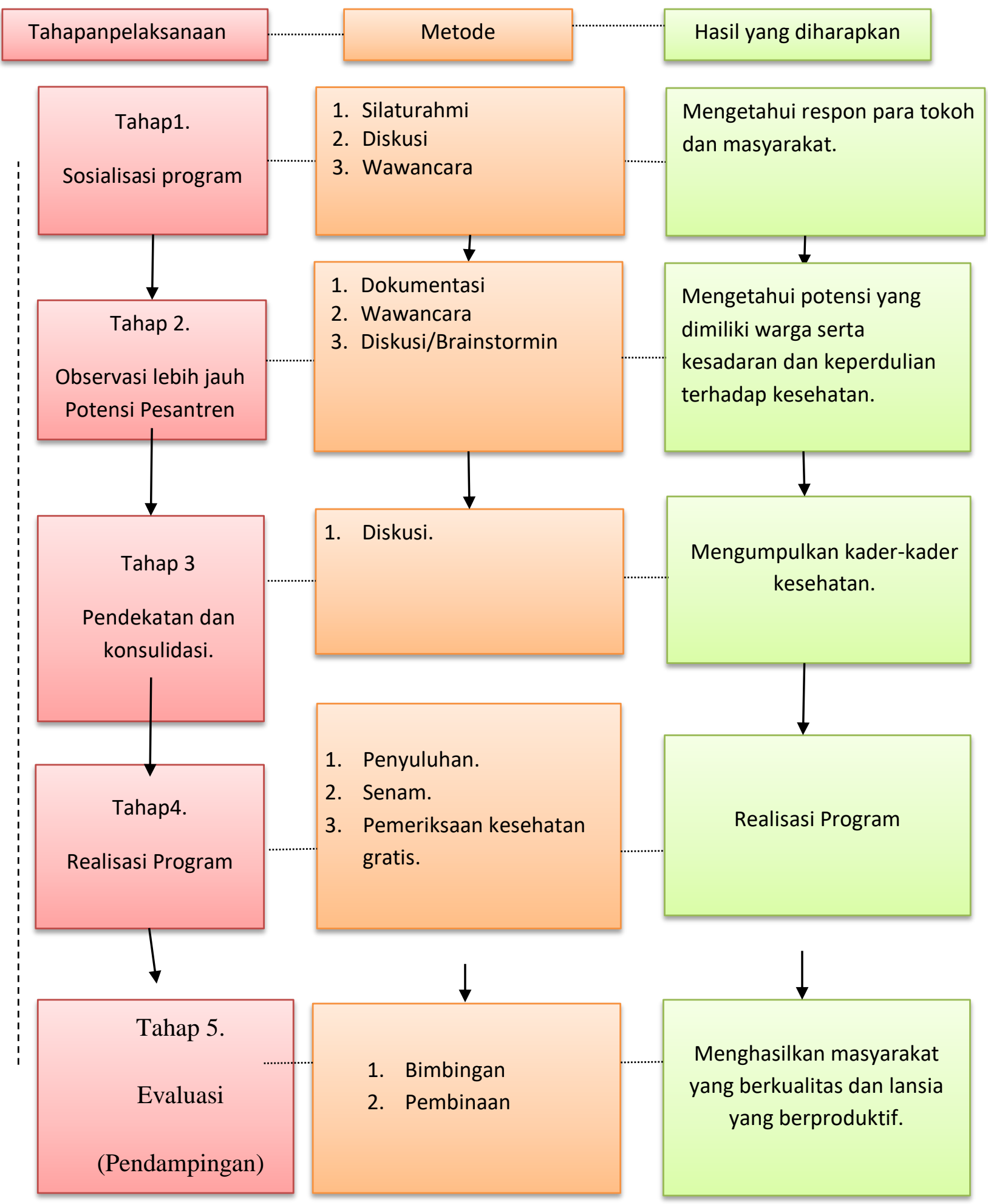




\section{Metode Pendekatan}

\section{Pendekatan Religious}

Pendekatan religious yang dimaksud adalah pendekatan dengan cara bergabung kedalam majlis ta'lim baik majlis ta'lim ibu-ibu maupun bapakbapak. Pendekatan religius ini dianggap perlu dilakukan di desa cibentang karena masih minim nya pengetahuan keislaman dan masih kuatnya mitos diantara masyarakat. Sehingga kami melakukan pendekatan dengan cara bergabung dalam pengajian agar pesan yang ingin disampaikannya dapat diterima oleh masyarakat.

\section{Pendekatan Organisasi}

Organisasi merupakan hal yang memiliki peran penting di tengahtengah masyarakat. Pendekatan organisasi di lakukan untuk mempermudah pengenalan kami kepada warga Desa Kalong I. Karena suatu himpunan dapat menjadi tolak ukur penilaian terhadap anggota yang tergabung di dalamnya.

3. Pendekatan Kekerabatan

Pendekatan kekerabatan dilakukan agar mudah berinteraksi, berdiskusi dan berbaur dengan masyarakat setempat. Serta agar program yang dijalankan dapat dibantu serta bekerjasama sesuai dengan kemampuan masing-masing.

4. Pendekatan Karakter Masyarakat

Dalam kehidupan di masyarakat banyak sekali perbedaan-perbedaan karakter setiap individu. Maka kami harus memahami perbedaanperbedaan tersebut. Sehingga dapat mempermudah terealisasikan nya program kerja yang telah kami rencanakan.

\section{Pendekatan Edukasi}

Desa Kalong I memiliki masyarakat yang memiliki latar belakang yang berbeda-beda. Tidak semua masyarakat mempunyai pengetahuan yang lebih modern dalam menjalankan kehidupan sehari-hari di lingkungannya. Maka dari itu pendekatan edukasi sangatlah di perlukan untuk mempermudah pendekatan dan pengenalan program kami kepada warga.

\section{HASIL DAN PEMBAHASAN}

\section{Pelaksanaan Program}

\section{A. Aspek Kesehatan}

\section{Pelayanan Kesehatan Lansia}

Pelayanan kesehatan lansia ini merupakan kegiatan yang diadaptasi dari kegiatan posbindu, kegiatan ini terdiri dari:

\section{Imunisasi}

Imunisasi ini merupakan pemberian vaksin yang di lakukan oleh petugas kesehatan puskesmas, vaksin yang di berikan merupakan vaksin Difteri.

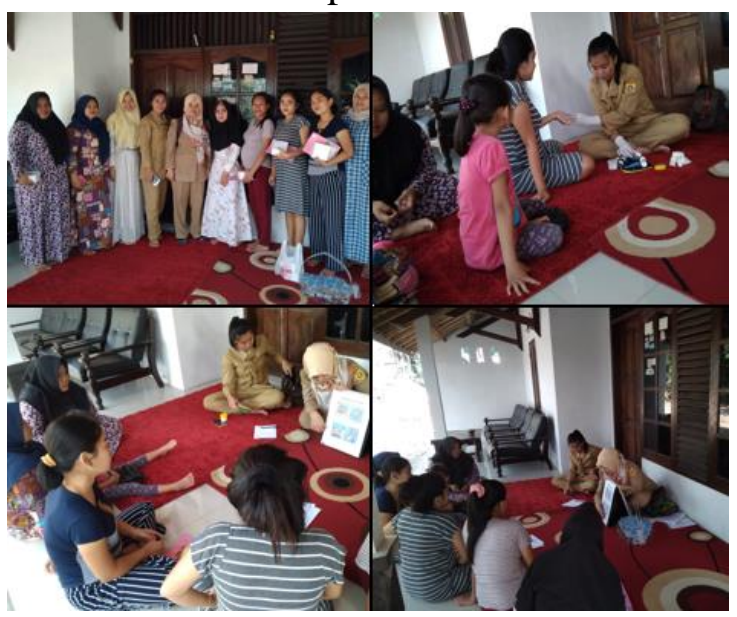

\section{Kelas Ibu Hamil}

Kelas hamil merukan kelas yang dilakukan khusu ibu hamil yang di lakukan 3bulan sekali. Kegiatannya terdiri dari: 


\section{Posyandu}

Kegiatan posyandu ini merupakan kegiatan bulanan yang dilakukan setiap 1bulan sekali, yang dimana kegiatan ini di laksanakan oteh petugas kesehatan puskesmas dan di bantu oleh beberapa kader untuk mengecek sekehatan bayi dan balita serta ibu hamil. Kegiatan ini terdiri dari:

\section{Penyuluhan PHBS}

Penyuluhan merupakan salah satu kegiatan mensosialisasikan upaya kesehatan sebagai tujuan meningkatkan kebersihan diri atau personal hygiene. Penyuluhan ini di lakukan 2 kali di 2 tempat yang berbeda dengan materi penyampaian yang berbeda pula, yaitu:

\section{B. Aspek Pendidikan}

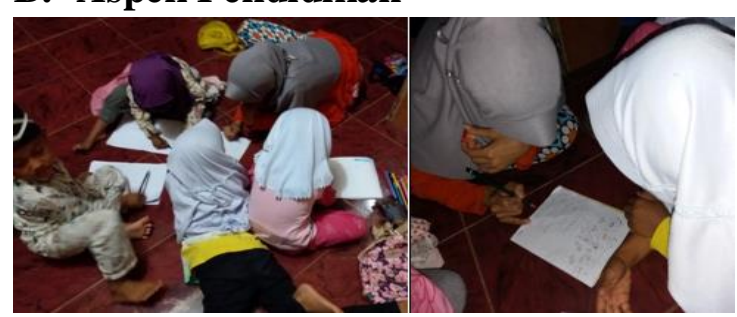

\section{Bimbingan Belajar}

Bimbingan belajar ini adalah kegiatan belajar mengajar untuk membimbing anak-anak dalam membantu mengerjakan pekerjaan rumah dan mengajarkan materimateri yang telah dan akan diajarkan Guru disekolah.

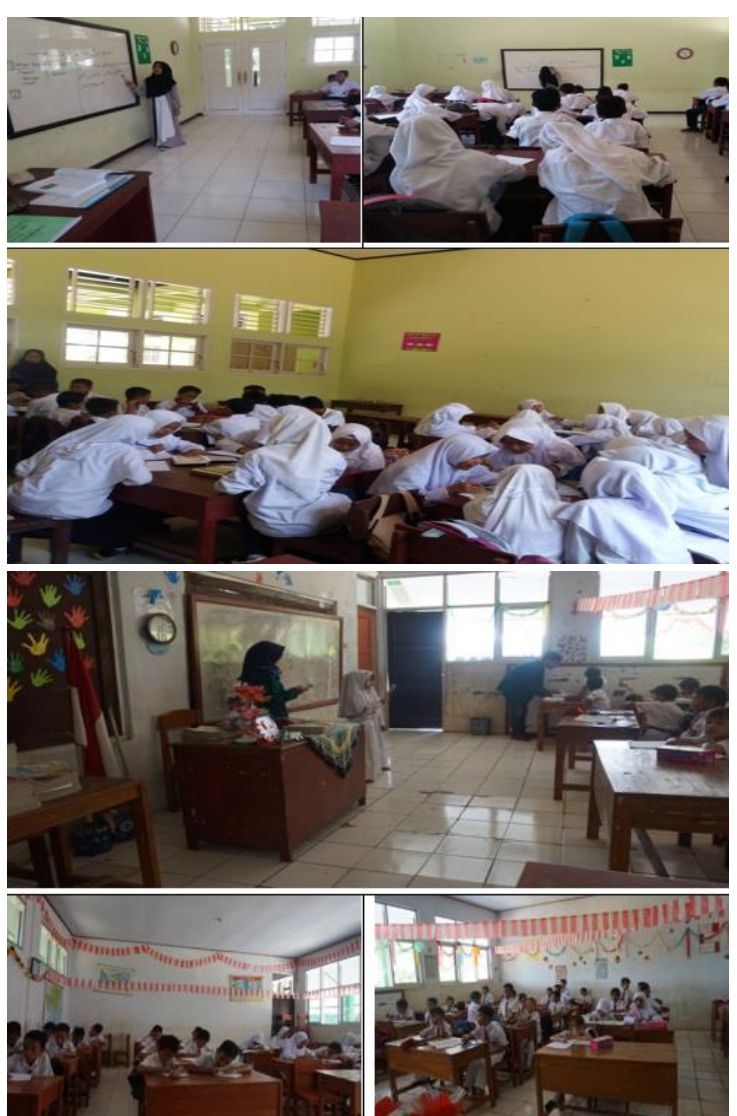

\section{Mengajar}

Dengan kegiatan Mengajar ini bertujuan mengaplikasikan ilmu yang telah didapat dikampus dan sekaligus membantu para Guru untuk mengajar saswa-siswi:

\section{Seminar}

Program kerja selanjutnya dalam aspek pendidikan yaitu mengadakan 2 seminar tentang Teknologi Informatika dan Komputer yang bertujuan untuk memberikan pengetahuan awal mengenai bagaimana cara mengaplikasikan komputer dan mengetahui perangkat-perangkat yang di gunakan untuk menggunakan komputer serta para siswa dapat mengetahui sejarah perkembangan komputer. Dan seminar kedua tentang Manfaat Menabung Sejak Dini yang bertujuan untuk memberikan pemahaman kepada anak-anak mengenai manfaat 
menabung sejak dini agar uang yang diberikan kepada mereka dapat dipergunakan dengan lebih baik lagi.

\section{Aspek Keagamaan}

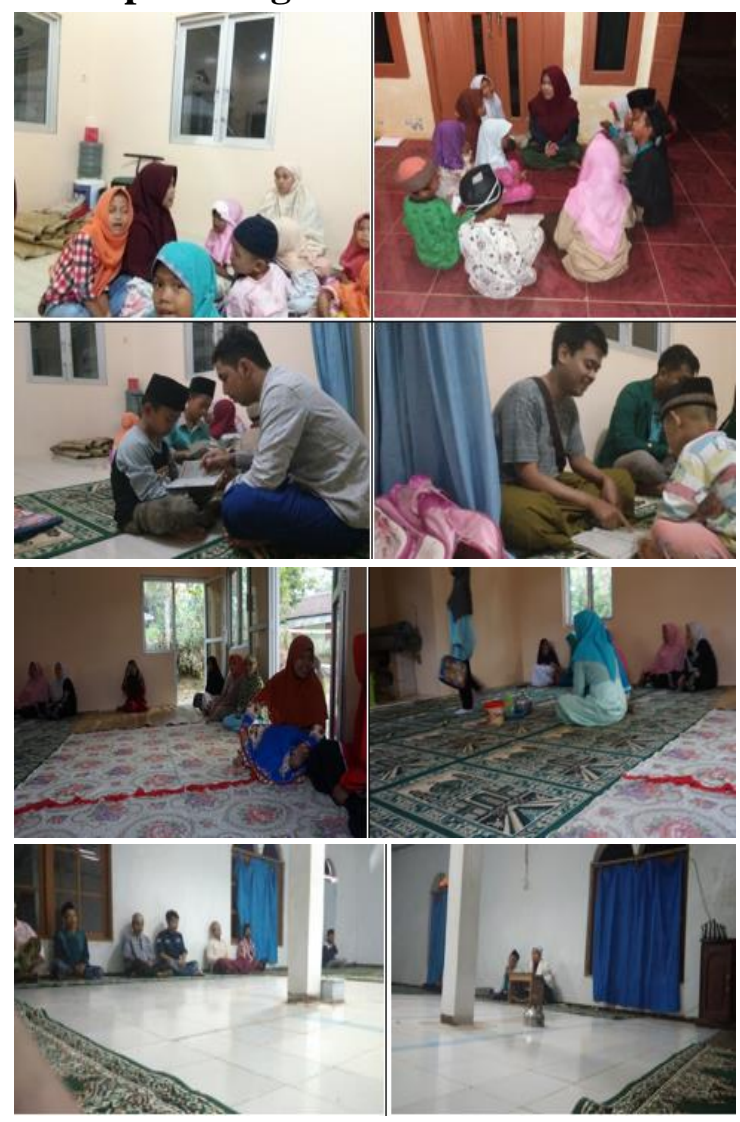

\section{Pengajian}

Pengajian ini dilakukan dalam 3 (tiga) bagian, yaitu : (1). Pengajian Bapak-bapak (2). Pengajian Ibu-ibu. (3). Pengajian Anak-anak. Dari ke-3 kegiatan pengajian tersebut memiliki tujuan yang sama, yaitu meningkatkan pengetahuan dan pemahaman masyarakat mengenai ajaran agama Islam. kegiatan yang dilakukan seperti: Membaca Alqur'an dan pendalaman ilmu agama.
D. Aspek Lingkungan

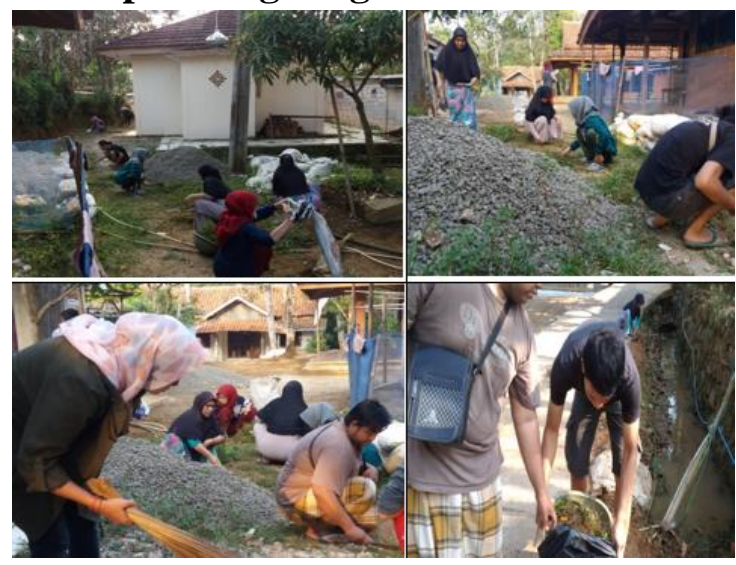

\section{Gotong-royong}

Gotong royong ini diharapkan mampu memberikan nilai positif bagi masyarakat, karena dengan gotong-royong mencerminkan kebersamaan yang tumbuh dalam lingkungan masyarakat. Masyarakat mau bekarja secara bersama-sama untuk membantu orang lain dan membangun fasilitas yang bisa dimanfaatkan bersama, seperti membersihkan jalan-jalan yang biasa dilewati oleh masyarakat setempat.

\section{Renovasi MCK}

Renovasi ulang MCK ini merupakan suatu kegiatan merapihkan ulang merefungsikan ulang kemabali MCK umum yang tadi sudah tak di pakai menjadi bisa di pakai kembali, dengan cara merapihkan MCK mencat ulang mengganti alat-alat yang rusak atau menambah alat-alat yan tidak ada.

\section{E. Aspek Hukum}

\section{Penyuluhan Penting}

Penyuluhan merupakan salah satu kegiatan mensosialisasikan upaya hukum dengan bertujuan masyarakat bisa tertib administrasi secara hukum dan agar masyarakat mengetahui betapa pentingnya memiliki surat 
berharga. Karena dengan memiliki surat-surat tersebut masyarakat juga akan memiliki kekuatan hukum bila terjadi sengketa.

\section{F. Capaian Program}

Alhamdulillah atas berkat rahmat Allah yang telah memberikan kemudahan untuk menyelesaikan program kerja ini, dan semuanya tidak terlepas atas dukungan semua pihak dan keterlibatan masyarakat, serta pemuda Karang Taruna dan aparat Desa Kalong I yang telah mendukung dan mau bekerjasama dengan kami, untuk melaksanakan program kerja yang telah kami rancang sebelumnya. Sebagian besar program kerja dapat dilaksanakan dengan baik meskipun masih jauh dari kata sempurna.

\section{KESIMPULAN}

Berdasarkan hasil $\begin{array}{r}\text { kegiatan, } \\ \text { pengamatan, maupun }\end{array}$ pelaksanaan
program kerja KKN yang telah
direncanakan, disusun dan dilaksanakan.
Maka kelompok 63 KKN UNIVERSITAS
IBN KHALDUN BOGOR 2018 di Desa
Kalong I Kecamatan Leuwisadeng mengambil beberapa kesimpulan yaitu :

1. Keberhasilan KKN tidak lepas dari kerja sama antara mahasiswa dengan perangkat desa, masyarakat, serta semua pihak yang membantu dan mendukung terlaksananya kegiatan KKN tanpa adanya kerja sama yang baik, program kerja KKN tidak akan berjalan dengan lancar.

2. Dengan adanya mahasiswa KKN para masyarakat mencoba mencontoh cara berfikir mahasiswa untuk befikir modern.

3. Dengan adanya mahasiswa $\mathrm{KKN}$ masyarakat terbantu dengan bertambahnya informasi dan ilmu pengetahuan yang mereka peroleh dari mahasiswa KKN

4. Teori yang didapat di bangku kuliah tidak semua sesuai dengan situasi dan kondisi lapangan.

5. Kurangnya kepedulian masyarakat desa terhadap lingkungan sekitar.

6. Potensi desa di Desa Kalong I telah dikelola cukup baik oleh masyarakat, sehingga tercapai hasil yang cukup memuaskan, diantaranya :

a. Kerjasama yang baik antara masyarakat, perangkat desa serta instansi terkait guna memperlancar pembangunan desa.

b. Keterbukaan aparat desa terhadap masyarakat, mampu menjalin hubungan komunikasi yang baik.
c. Pemberdayaan swadaya masyarakat untuk menunjang pembangunan desa.

d. Pemberdayaan BPD, LKMD, PKK, dan Karang Taruna.

Dengan demikian, hasil kesimpulan di atas menunjukan bahwa secara garis besar program KKN kelompok 63 dapat dikatakan sukses dan lancar meskipun ada beberapa kendala baik dari pihak mahasiswa maupun pihak masyarakat di Desa Kalong I namun itu tidak berpengaruh terhadap program yang telah direncanakan. 


\section{Dampak Bagi Masyarakat}

\section{a. Aspek Kesehatan}

\section{Senam Sehat Lansia}

1. Memberikan Kebugaran Jasmani dan Rohani

Senam merupakan aktivitas yang bernilai positif, mampu memberikan manfaat yang baik untuk tubuh.

2. Meningkatkan fungsi jantung Gerakan senam yang dilakukan secara kontinyu dan berulangulang membuat jantung bekerja dengan cepat.

\section{b. Aspek Pendidikan}

1. Menciptakan anak-anak yang cerdas dan aktif

Rasa percaya diri seorang anak akan tumbuh dengan sendirinya ketika mengikuti bimbingan belajar. Lewat bimbel ini anak akan aktif bertanya dan dari sanalah membuat anak lebih aktif serta menumbuhkan minat untuk berkompetisi menjadi lebih baik.

2. Mendapatkan Bimbingan Belajar waktu positif Anak.

Bimbingan Belajar tidak hanya membuat anak lebih pintar, tapi pelajaran juga dapat memberikan waktu yang positif bagi anakanak sendiri. Anak-anak akan terhindar dari pergaulan yang buruk, karena menghabiskan waktu dengan kegiatan yang positif, dengan demikian para orang tua tidak perlu khawatir dengan kegiatan anak-anaknya.

\section{c. Aspek Keagamaan}

1. Meningkatkan kualitas ketakwaan terhadap sang Maha pencipta
Dengan adanya kegiatan Pengajian diharapkan masyarakat semakin Takwa dan semakin giat dalam beribadah dan berbuat baik terhadap sesama.

\section{d. Aspek Lingkungan}

1. Meningkatkan rasa kepedulian warga terhadap kebersihan lingkungan

Masyarakat yang peduli kebersihan lingkungan adalah masyarakat yang telah sadar akan pentingnya kesehatan.

2. Suasana lingkungan yang nyaman, tentram, asri, menyenangkan dan jauh dari wabah penyakit .

3. Oksigen yang dihiruppun segar, dan bagus untuk pernapasan

4. Jiwa semangat gotong-royong Masyarakat yang memiliki rasa kepedulian yang tinggi akan senantiasa membantu saudara, tetangga dan kerabatnya dalam melakukan hal apapun yang positif.

5. Menumbuhkan rasa solidaritas antar warga

Warga memiliki perasaan yang peka terhadap sesama, rasa simpati dan empati terhadap warga setempat.

\section{e. Aspek Hukum}

1. Agar masyarakat mengetahui betapa pentingnya surat-surat (surat tanah, akte kelahiran, kartu keluarga, Dll).

2. Agar masyarakat memiliki suratsurat penting itu. 
SARAN

Sebagai evaluasi dan upaya perbaikan dalam penyelenggaraan program Kuliah Kerja Nyata (KKN) yang akan datang, baik bagi panitia penyelenggara, peserta, dosen pembimbing lapangan, maupun masyarakat sebagai sasaran KKN, maka kami memeberikan rekomendasi sebagai berikut :

1. Bagi peserta Kuliah Kerja Nyata (KKN) Tematik Terintegrasi 2018 UIKA Bogor.

a. Lebih memepersiapakan diri, dalam arti telah siap dengan wawasan pengetahuan, fisik dan psikologi masyarakat agar dapat membaur dan memahami permaslaahan secara tepat dan komprehensif.

b. Lebih mempersiapakan diri mengenai kedisiplinan ilmu yang dimiliki serta lebih memiliki rasa tanggung jawab dalam melaksanakan tugas.

c. Lebih dapat mengontrol diri, emosi, menjaga lisan dan memperhatikan akhlakul karimah sebagai mahasiswa selama KKN berlangsung.

d. Lebih realistis dalam merencanakan program sesuia dengan kemampuan SDM dan anggaran dana.

e. Lebih mempererat tali silaturahmi dengan masayarakat atau sasaran $\mathrm{KKN}$, serta dapat melebur dengan kegiatan keseharian mereka.

f. Lebih meningkatkan komunikasi yang baik, kerjasama, dan solidaritas antar sesama anggota kelompok KKN, agar lebih menumbuhkan suasana kekeluargaan, kebersamaan, dan keakraban, mengingat anggota KKN ini hakikatnya tetap satu naungan Universitan Ibn Khaldun Bogor.

2. Bagi Dosen pembimbing lapangan Diharapakan dapat lebih mengontrol dan membimbing setiap kegiatan yang dilaksanakan oleh peserta KKN agar berjalan baik dan lebih terarah.

3. Bagi panitia

Hendaknya dalam melaksanakan pembekalan dan pembagian kelompok, lebih diperhatikan lagi untuk lokasi penempatan peserta KKN karena di beberapa lokasi terjadi halhal yang kurang menyenangkan untuk para peserta. Serta ketika memberi pembekalan diharapkan untuk memastikan bahwa setiap kelompok sudah benar-benar mengerti akan materi yang disampaikan.

Atas segala dukungan, dan bnatuan serta kepercayaan yang diamanahkan, kami mengucapakan terimakasih yang sebesar-besarnya kepada seluruh pihak yang terkait. Semoga hal-hal yang telah dilakukan bernilai ibadah dan menjadi amal sholeh serta dapat bermanfaat. 


\section{REFERENSI}

Administrasi Profil Desa Kalong 1 Kec. Leuwisadeng Kab. Bogor

Bahari. (2010). Toleransi Beragama Mahasiswa (Studi tentang Pengaruh Kepribadian, Keterlibatan Organisasi, Hasil Belajar Pendidikan Agama, dan Lingkungan Pendidikan terhadap Toleransi Mahasiswa Berbeda Agama pada 7 Perguruan Tinggi Umum Negeri. Jakarta: Kementerian Agama RI Badan Litbang dan Diklat Puslitbang Kehidupan Keagamaan.

Gall, M.D., Gall, J.P. dan Borg,W.R. (2003). Educational Research an Introduction. Boston: Pearson Education, Inc.

Joyce, Bruce dan Weil, Marsha. (1996). Models of Teaching. Boston: Allyn and Bacon.

Kusumadewi,L.R. (1999). Sikap dan Toleransi Beragama di Kalangan Mahasiswa: Studi di Tiga Perguruan
Tinggi di Jakarta. Skripsi. Depok: FISIP UI.

Pelaporan Pedoman PPM Universitas Ibn Khaldun Bogor. 2017

Slavin, R.E. (2005). Cooperative learning: theory, research and practice. London: Allyn and Bacon.

Talib,A.T dan Gill, S.S. (2012). Socioreligious tolerance: exploring the Malaysian experience. Global Journal of Human Social Science. 12(8). 49-54.

Tim Penyusun. (2008). Toleransi dalam Pasungan: Pandangan Generasi Muda terhadap Masalah Kebangsaan, Pluralitas dan Kepemimpinan Nasional. Jakarta:SETARA Institute.

Tim Peneliti. (2006). Laporan Hasil Survei Pengetahuan, Sikap dan Perilaku Stakeholders terhadap Organisasi Masyarakat Sipil. Jakarta: LP3ES dan YAPPIKA. 